\title{
An Organizational Framework for Logistic Platform and its Subtypes in a Search for More Logistically Attractive Regions
}

\author{
Brigita GAJŠEK 1 , Jure KOVAČ², Benjamin T. HAZEN \\ ${ }^{1}$ Faculty of Logistics, University of Maribor, Mariborska cesta 7, SI-300 Celje \\ brigita.gajsek@um.si \\ ${ }^{2}$ Faculty for Organizational Sciences, University of Maribor, Kidričeva cesta 55a, SI-4000 Kranj \\ ${ }^{3}$ Department of Operational Sciences, Air Force Institute of Technology, Wright-Patterson Air Force Base, OH, USA
}

\begin{abstract}
Background and Purpose: Regional sustainable economic growth on logistics bases requires the coordinated development of infrastructure, information and communications technology, and proactive education of logistics specialists. The goal is reachable with regional logistics platforms (RLPS). This current research develops a theoretical model for RLPs, consisting of (1) basic constituents, (2) an implementation area, and (3) stakeholders' and operational benefits.

Design/Methodology/Approach: We employed a balanced qualitative and quantitative approach using multiple case study and survey methods.

Results: Systematic case study research has identified 12 "most frequently" highlighted RLP constituents and 3 areas of implementation, which were further proven by a survey. RLP's beginnings may be spontaneous until a critical mass of interested stakeholders emerges with a clear vision and start-up energy for a breakthrough. A theoretical model for RLPs is proposed.

Conclusion: The secret of a successfully developing a logistics region lies in its ability to develop a mechanism for the managing and coordinating a particular logistics system's development and operation, an area that should be further researched. This study's findings provide valuable insights into the many aspects of RLPs, which can be useful for regional authorities and business owners who are eager to stimulate regional economic growth.
\end{abstract}

Keywords: logistics platform; organizational structure; networking; governance, regionalization; transportation

\section{Introduction}

Market globalization and increased competition urge producers, distributors and vendors to integrate their operations, thus developing widespread networks for managing materials, products, information and capital (Villa, 2001). To aid businesses in these efforts, scholars (e.g. Nguyen and Tongzon (2010), Liedtke and Murillo (2012), and Monios (2015)) call for the need to better integrate intermodal transport and logistics, and to understand the related, evolving governance relationships. Many years of research, interdisciplinary thinking and experiments in practice have shown the need for organizational restructuring, and alternative modes of governance. New structures provide an opportunity for improved efficiency, higher utilisation of resources, new technologies, innovation, improved interoperability among transport modes, coordination of the supply chain (SC), removal of administrative barriers, and sustainable environmental behaviour. However, coordinated approaches toward policy-making that 
will evoke such improvements have yet to be fully defined. In this paper, we propose and examine one such approach by defining the concept of a regional logistics platform, its basic constituents, geographic/business areas of implementation, and implementation effects.

Today, globalization and the use of information and communication technologies (ICT) reduce dependency of businesses on their geographic locations (Lucking-Reiley \& Spulber, 2001; Sahney, 2015). With e-commerce's rapid development, the business world's focus is passing from quantity production to circular economy (Weng \& Zhang, 2015). Also, transport costs for long-distance cargo movements are gradually decreasing (Twrdy, Peterlin, Žaucerm \& Jenček, 2007). This decrease is due to many reasons, such as the use of new optimal routing and refueling policies (Suzuki \& Dai, 2012) and the advent of structural integration of SCs (Morash \& Clinton, 1997). It is becoming obvious that for global trade to increase the effectiveness of physical exchange between geographically dispersed enterprises, it is insufficient merely to modernize ICT in response to more frequently required physical redirection of trade flows to new geographical areas.

Over time, organisations have implemented new and maturing SC strategies (Christopher \& Towill, 2002) as well as contemporary tools and techniques in logistics and transportation (Vogt, 2010). Furthermore, these advances have led to adopting new SC practices that have elevated the role of SC management and SC integration within many organisations (Stevens \& Johnson, 2016). Researching SCs is in the forefront of scientists' efforts, yet changing SCs' impact at the regional level is largely overlooked.

Business-oriented regions are striving to become more attractive for settlement and business activities in the eyes of the general public, businesspersons, companies, and other stakeholders. In these cases, the emphasis is on an "attractive" and "friendly" region, and more precisely, a "logistically attractive and friendly" region. Goods from China, for example, can arrive through different transportation modes to inner-European states via Western or Southern ports as continental entry points. This detail may be unimportant for a specific freight forwarder, producer or SC; but it is essential for any country that operates and develops based on tax revenue.

We consider three key functional groups as enablers of global material flow: (1) the SCs as a source of objects in the material flow, (2) providers of material flow (logistics, transportation, customs, information-communication enablers) and (3) the regions as territory managers and supervisors of infrastructure resources. Stevens and Johnson (2016) described the SC operating model of the future as taking the form of autonomous, adaptive fulfilment communities. Contemporarily, logistics and transportation in any region are a medium allowing exchange between different business formations that need not necessarily be located within the region. SCs may also develop their logistics systems, but this practice is no longer the only one possible due to the large financial input and the loss of flexibility. According to the European Commission (2015), logistics service providers perform about one-half of all logistical activities, but the degree of outsourcing in contract logistics remains low, which does not allow them to tap into their full potential. The European logistics market accounts for $€ 960$ billion in 2014 and transports 18.6 billion tons (Kille, Schwemmer \& Reichenauer, 2015). Indeed, the third-party logistics industry is expanding (Marasco, 2007), and the competition between countries for taking over material flows as a result of SC's industrial activities is increasing. Evidence suggests that industry prefers globally established logistics providers rather than solely regional providers (Schwemmer, 2016).

Li-Ekenstedt (2004) and Du and Bergqvist (2010) identified several important factors in multinational corporations ' decision-making processes regarding determining where to locate logistics infrastructure. These factors imply (1) that a firm's relocation decision, or the triggering of material flows through a select territory, requires consideration beyond simply a region's geographically favourable location and (2) that regions and cities with historically favourable geographical locations could influence the degree of their attractiveness in conducting production and logistics activities. The challenge clearly lies in how to encourage breakthrough activities within the logistics sector with the support or guidance of regional policy makers and industry stakeholders.

In reviewing developments in various European regions, we have noticed that some regions (e.g., Zaragoza Province in Spain) seem to know exactly how to become logistically attractive and, subsequently, realize economic growth (Sainza, Bañosb, Valc \& Jose, 2013). In reviewing the examples of France (Francetech, 2001) and Switzerland (Swiss Logistics Platform, 2015), we see the possibility of increasing a region's logistics attractiveness by establishing regional logistics platforms (RLPs). Logistics performance indices (LPI) for both countries were ranked in the top quintile of the World Bank Group's survey on trade logistics for 2014 (Arvis et al., 2014) and are considered to be „logistics friendly.“ France's transport and logistics market is estimated at $€ 124.7$ billion, making it the second largest logistics market in Europe after Germany (Kille, Schwemmer \& Reichenauer, 2015). However, viewing the logistics platform (LP) as the concept for promoting economic growth within regions fails to coincide with traditional views.

Traditionally, LP has been a hypernym for Automotive Supplier Parks in the German automotive industry (Pfohl \& Garies, 2005), freight gateways or hubs (Bolumole, Closs \& Rodammer, 2015), intermodal logistics platforms (Cambra-Fierro \& Ruiz-Benitez, 2009), logistics centres (Meidute, 2005), cross-docks (Kinnear, 1997), and similar formations. In this paper, we will further explore the LP 
concept's use within regions or countries because we suspect that the modern LP interpretation has outgrown the hypernym and will soon develop into a hierarchical, multi-level structure (Gajšek \& Grzybowska, 2013; Gajsek \& Rosi, 2015; Grzybowska \& Gajšek, 2016).

The purpose of this paper is to define the concept of LP, with special focus on RLP as a sub-type, its basic constituents, geographic/business areas of implementation, and the implementation's effects. We consider how LPs and also RLPs involve not only constructing buildings, purchasing machinery and employing people, but also managing and coordinating regional logistics systems' development and operation. This research consolidates different views on who should initiate/develop/finance/manage/operate the logistics system and its resources within a region as well as what "logistics" should entail. Our proposed solution takes the form of an RLP model, which can help to inform regional growth and subsequent economic development.

\section{Theoretical background}

The complexity of today's SC systems means that it is nearly impossible to explain an SC phenomenon with a single theory (Chen, Daugherty \& Landry, 2009). Based on our review of the literature, we conclude that scholars commonly use transaction cost economics (TCE), resource-based view (RBV) and strategy-structure-performance (SSP) framework when examining formation and structure of LPs. Addressing RLPs, which enables SC's global operations in a certain region, however, requires an even broader theoretical framework, including new institutional economics and social network theory.

According to TCE, firms adopt a variety of relationships with each other to lower transaction costs associated with a purely transaction-based arrangement whereby relationships are based on market contracts (Coase, 1937; Williamson, 1975; Berquist \& Monios, 2014). Basic tenets of TCE apply both to inter-company relations and intra-company operations, and considerations based on this theory support the value of integration of production and logistics (Chikan, 2001). Berquist and Monios (2014) described how RBV is based on the management of resources within the firm (Barney, 1991; Wernerfelt, 1984) and increasingly, across all actors in an SC (Dyer \& Singh, 1998; Lavie, 2006; Peters et al., 2011; Schmoltzi \& Wallenburg, 2011). Following an RBV approach, increasing the number of partners in the cooperation agreement provides more resources from which to benefit, whereas according to TCE, communication and coordination become more complex as the number of organizations increases (Schmoltzi \& Wallenburg, 2011). RLPs are pools of resources whose consistency and planned regional use could contribute to greater efficiency of the regional system.

Applications of TCE and RBV provide the basis for constant improvement of existing and new organizational forms of governance models, based on the integration of new organizations and stakeholders, and are widely employed in logistics research (Berquist \& Monios, 2014). Governance can be defined as a process of distributing authority and allocating resources and includes managing relationships, behaviour, and processes to achieve a desired outcome (Berquist \& Monios, 2014). Addressing regional logistics and transport issues is beyond the scope of operators and owners of logistics/transportation infrastructure components.

Drawing on the new institutional economics' body of literature, researchers have explored governance models in individual logistics and transport organizations, to include topics of port governance (Monios \& Wilmsmeier, 2013) and intermodal terminal governance (Berquist \& Monios, 2014). The question of how to comprehensively govern logistics and transportation activities in the region to optimize the economic and environmental well-being of the region remains unanswered.

According to strategy-structure-performance (SSP) theory, a firm's strategy drives the development of organizational structure and process, which should also apply to the regional level (Miles et al., 1978) and SC's (Clifford Defee \& Stank, 2005; Perez-Franco et al., 2016). By passing ownership or management of state-owned enterprises to the private sector, the state loses direct control over a given regional logistics system, which can shape performance and environmental friendliness of trade flows. There is a dearth of understanding regarding organizational models connecting antecedents of regional logistics and SC capability that would stimulate economic growth within a defined region (Closs et al., 2014) or descriptions of "the conscious pursuit of joint action" (Schmitz \& Nadvi, 1999). The logical next step would be to define and describe "regional governance" as an outcome of proactive inter-organizational action aimed at capitalizing on localized resources so as to drive competition with other regions. Bolumole and colleagues (2015) stated that regions compete by providing a platform to maximize productivity in ways that support their economic development goals of job creation, attracting investments, and achieving a high return on infrastructural investments. Also, one might also include preserving agricultural land and living environment.

These advances can be seen through the lens of social network theory. In all subfields of political science in the last third of the twentieth century, the world witnessed a transformation of political order from organizations/hierarchies (and markets/anarchies) toward networks (Blatter, 2003; Marolt et al., 2016). Intermodal terminals are no longer exclusively controlled by a central unit like the state. Rather, controlling devices are dispersed, and material resources and information are shared by a multiplicity of divergent actors. The coordination of these actors is not the result of "central steering," but instead emerges through the purposeful interactions of many individual actors. 


\section{Literature Review}

While searching for ways to make the region logistically friendlier, a review of existing literature has led us to conclude that the LP model is one of the contemporary business strategies that has attracted broader attention in the last decade. Academic literature reveals that LPs were sometimes equated to cross-docking warehouses at the turn of the millennium (Cambra-Fierro \& Ruiz-Benitez, 2009; De Souza, Da Silva Costa \& Gobbo Junior, 2007; Du \& Berqvist, 2010). The evolution of logistics (Rutner, Aviles \& Cox, 2012) caused a widespread adoption of the LP concept outside the boundaries of individual enterprises and SCs. In academic literature today, there is no consensus on what an LP is. Authors use the term in a wide variety of contexts, ranging from a group of workers (Del'olmo \& Lulli, 2004) to a means for exchanging and evaluating all types of information that may affect activities within the supply channel (Váncza, Egri \& Karnok, 2010). On the one hand, an apparent gap exists in research and expert literature; on the other, the practice strongly indicates a need for efficient logistics operations both inside and outside the boundaries of individual enterprises/SCs. Worldwide, several logistics trials and pilot projects have been dedicated to establishing LPs or in some cases RLPs, going beyond the framework of a logistics center. In practice, this situation confirms that strictly equating the LP or RLP ${ }^{1}$ with a cross docking warehouse is no longer possible. Our survey was guided by the assumption that an (R)LP involves not only constructing buildings, purchasing machinery and employing people but also establishing a mechanism for a regional logistics system's development and operation.

A review of the academic literature in this field revealed 27 articles mentioning the (R)LP concept. Each of them relate to a specific example taken from practice (i.e., some fashion of case study) (Figure 1). The authors endeavoured to present a comprehensive definition of LP, but the definitions differ because the LPs were studied at different levels of detail as well as in different circumstances and time periods. According to Rutner et al. (2012), the evolution of logistics has spanned six eras and is still unfolding. Logistics' development involved short movements from farms to markets to movements across the globe today, in particular with respect to the implementation of intermodalism (Jennings \& Holcomb, 1996). Thus, logistics' evolution analogously reflected on evolution of LP and its subtypes.

In reviewing the academic literature, we identified important findings in the correlation of the structure, the implementation area, and the LP concept's characteristics. (Figure 1). The structure refers to observed constituents mentioned in conjunction with an individual LP. The area is business or geographic space in which the LP is imple- mented and not merely a geographic space determined by unique geographic coordinates. The literature review also revealed that in practice, implementing an LP can be independent of physical location because some LPs can be moved within the geographical space while maintaining their constituents and characteristics. For example, when an LP is equated to a warehouse, the specific company can build several identical LPs in different locations across the globe. An LP's characteristics include the type of ownership, the strategic objectives' existence and content, the operations' effects, and the types of operational phases in which stakeholders are involved.

Upon reviewing the literature, we observed several areas the LP concept covered: company, SC, country, and region. Consequently, we first propose the following division of LPs for verification: company LP (ComLP), supply chain LP (SCLP), country LP (CouLP), and RLP. The latter is the subject of our current research. Considering RLP phenomenon's newness and the above review, the following research questions were developed to guide our investigation regarding how RLPs can lead to more efficient SC operations, SC operations' growth at a regional level, and characterizing logistics-friendly locations:

- RQ1. What are the most frequently highlighted LP constituents concerning company, $\mathrm{SC}$, region, and country?

- RQ2. Is RLP formation a result of established regional strategies?

- RQ3. What are RLP implementations' effects?

\section{Methods}

Considering the research questions as well as Golicic, Davis and McCarthy's (2005) recommendations, we used a balanced research methodology that included both qualitative and quantitative approaches.

\subsection{Multiple case studies}

Our reasoning for using a qualitative approach was that the RLP is a new phenomenon and comprehensive theory is not available for its interpretation. The research included a study of multiple LPs through detailed, in-depth data collection and a report on case descriptions. We examined multiple case studies with the same protocol to check for repetitive patterns. Construct validity was ensured in the following ways: using data collected from multiple sources for the purpose of triangulation, following a precisely described methodology, ensuring transparency and traceability during data collection and analyses, and having participants review transcripts and case reports.

Based on the previously described literature review, we concluded that LPs are divided into the following four

1 LP or RLP - abbreviated R(LP) 


\begin{tabular}{|c|c|c|c|c|}
\hline & \multicolumn{4}{|l|}{ Type of LP } \\
\hline & Company LP & Supply chain LP & Country LP & Regional LP \\
\hline \multicolumn{5}{|c|}{ Constituent Parts of LPs } \\
\hline $\begin{array}{l}\text { Transportation } \\
\text { infrastructure }\end{array}$ & & & $\sqrt{ }$ & $\sqrt{ }$ \\
\hline $\begin{array}{l}\text { Logistics } \\
\text { infrastructure }\end{array}$ & $\sqrt{ }$ & $\sqrt{ }$ & & $\sqrt{ }$ \\
\hline $\begin{array}{l}\text { Technological } \\
\text { equipment/logistic } \\
\text { specialists }\end{array}$ & $\sqrt{ }$ & $\sqrt{ }$ & & \\
\hline $\begin{array}{l}\text { ICT to support } \\
\text { logistics' activities }\end{array}$ & $\sqrt{ }$ & $\sqrt{ }$ & & \\
\hline \multicolumn{5}{|l|}{ Authors } \\
\hline & $\begin{array}{l}\text { Abrahamsson et al. } \\
\text { (2003); Dell'Olmo } \\
\text { and Lulli (2004); Lieb } \\
\text { and Bentz (2005); } \\
\text { Pekkarinen and } \\
\text { Ulkuniemi (2008); } \\
\text { Lin et al. (2010); } \\
\text { Nunez-Carballosa and } \\
\text { Guitart-Tarres (2011); } \\
\text { Bonev et al. (2015) }\end{array}$ & $\begin{array}{l}\text { Pfohl and Gareis } \\
\text { (2005); Sanchez and } \\
\text { Villalobos (2007); } \\
\text { Váncza et al. (2010); } \\
\text { Sprague and Wool- } \\
\text { man (2011); Almotairi } \\
\text { (2012); Gattuso and } \\
\text { Cassone (2012); Guy- } \\
\text { on et al. (2012); }\end{array}$ & $\begin{array}{l}\text { Nunez-Carballosa and } \\
\text { Guitart-Tarres (2011) }\end{array}$ & $\begin{array}{l}\text { Dubke et al. (2006); } \\
\text { De Souza et al. (2007); } \\
\text { Johannsen and Kristian- } \\
\text { sen (2007); Mangan and } \\
\text { Lalwani (2008); Lin and } \\
\text { Ho (2009); Leal and Pérez } \\
\text { Salas (2009); Cambra-Fi- } \\
\text { erro and Ruiz-Benitez } \\
\text { (2009); De Carvalho et al. } \\
\text { (2010); Lima et al. (2011); } \\
\text { Lăpăduşi and Brăncuşi } \\
\text { (2011); Antún and Alarcón } \\
\text { (2014); Mozart da Silva et } \\
\text { al. (2014) }\end{array}$ \\
\hline
\end{tabular}

Figure 1: Constituents and stakeholders in relation to different LPS

groups, according to the area of implementation: ComLP, SCLP, RLP and CouLP. This division served as the primary guide for determining the number of practical cases and in making the selection. For each of the four groups, two or three replications were retrieved to verify the similarities/ contrasts of results among replications within and among groups, as recommended in Ellram's (1996) work.

Because relatively few companies, SCs, countries, and regions publicly discuss their LPs, this study used a purposive sample. To select high quality cases, several academics were contacted. We compiled a list 36 LPs of various types and then identified their web and gatekeeper email addresses. In reviewing their websites and interviewing local logistics experts, we discovered that some initiatives were ended, suspended, had no real activity, or eventually failed. Only 10 logistics platforms of the 36 identified were able to make a breakthrough and continue evolving.

Email correspondence was sent in January 2014. The correspondence included a survey description and a request for recipients to be interviewed. We received four responses within one week. The remaining potential participants were solicited, but no other responses were received. The four persons who responded were interviewed via Skype. As part of the case study method, we used not only semi-structured interviews with competent employees but also structured observations of LP's web pages and other documentation, and content analyses of records and artefacts to provide validity through triangulation.

\subsection{Survey}

We surveyed logistics professionals employed in four types of organizations (logistics, production, educational/research, public body) from three countries. Singapore is the world's busiest transhipment hub, handling about one-seventh of the world's container transhipment throughput. Poland ranks in the top quintile of the logistics performance index (LPI), and Slovenia ranks in the second quintile of LPI (Arvis et al., 2014).

The selection of logistics companies was based on companies classified under "Section $\mathrm{H}$ - traffic and warehousing: medium and large enterprises, " and the selection of production companies was based on companies classified under „Section C - manufacturing: large enterprises“ as found in the Standard Classification of Activities. The 
selection of educational/research institutions was based on higher education institutions that provide students with cutting-edge logistics knowledge. The respondents selected from public bodies (PBs) included those employed in state authorities, at the Chamber of Commerce or its affiliates and logistics associations' personnel. Only key experts from the logistics field were included.

To ensure the questionnaire's clarity and relevance as a survey instrument, three academic experts and two industry experts were asked to review it. Their input was used to develop the final questionnaire, which, excluding the demographics section, consisted of three questions with sub-questions. Responses were provided in the form of a five-point scale.

The survey was web-based. Qualified respondents and their relevant contact details were collated with the assistance of the Slovene Chamber of Commerce, the Poznan University of Technology and the National University of Singapore. Data were collected over a three-week period in March 2014, yielding 220 completed surveys: 89 in Slovenia, 95 in Poland, and 36 in Singapore. In Slovenia, two responses were excluded from the analysis because the respondents indicated that their companies no longer operated in the logistics industry. In Poland, 22 questionnaires of the 95 sent were received without demographic data from respondents, who answered with „No“ or „Not sure“ for the questionnaire's first question. These questionnaires were excluded from further detailed analysis. As a result of the small sample sizes and non-normally distributed data, two non-parametric tests were used to verify discrepancies: the Kruskal-Wallis H test and the Mann-Whitney test.

The first question was: Have you been exposed to the idea of a „logistics platform“ before? In Singapore, 34 respondents answered with „No" and two with „Not sure“. Only two questionnaires with a "Yes" response could be included in our detailed analysis. On the basis of this outcome, we concluded that the term "logistics platform“ is little used/known in Singapore. But this does not prove that similar or even identical formations do not exist in the country.

Based on respondents' answers, the remaining questionnaires were divided into two groups: one being respondents who had previously encountered the LP concept (67.5\% of those questioned), the other being those who had never encountered the LP concept or were uncertain $(32.5 \%)$.

The second question was: What elements should be included in the characterization of logistics platforms? We provided the respondents with the description of 12 constituents of LPs, as determined by reviewing the academic literature and case studies. This question consisted of 13 sub-questions, 12 ,closed“ and one „open.“ The latter allowed for the inclusion of one or more constituents that may have been overlooked.

The third question was meant to examine perceptions about the geographic/business areas. Within this context, we attempted to determine the range within which LPs had been associated, i.e. whether LPs as perceived by the respondents had manifested themselves at the company, SC, country, or regional levels.

\section{Results}

\subsection{Results from Case Studies}

In exploring case studies, we focused on the structure, application area, and benefits of applying the LP concept in practice. We selected ten representative cases of LPs according to the geographic/business areas in which individual LPs operate:

- Company LPs: DIA (operates in Brasil, Argentina, Spain and China), GEFCO (a global logistics player), Rail Cargo Austria;

- Supply chain LPs: EURO-LOG/24plus, DEUTZ AG/ AX4 LP (operates in Argentina, USA, Spain, Germany, China);

- Regional LPs: Femern Belt LP, Logistics in Wallonia (Belgian), Zaragoza LP (Spain);

- Country LPs: France as a LP, the Swiss LP (LPI in the top quintile);

What are the most frequently highlighted LP constituents regarding company, SC, region, and country?

Systematic case study research has identified 12 "most frequently" highlighted LP constituents: geographical position, business environment, traffic infrastructure, logistics infrastructure, logistics technological equipment, logistics technology, ICT logistics support, logistics specialists, logistics companies, regulations for logistics companies ${ }^{6}$ needs, a joint interactive portal, and an organized group of stakeholders. In addition, the data revealed differences in highlighted constituents according to the geographic/business area in which an individual LP operates (See Figure 2). Each non-coloured box at the intersections of constituents and LP types in Figure 2 indicates that a given constituent is not frequently mentioned in connection with a particular type of LP.

We may conclude that the same constituents are used to describe RLPs in regions and CouLPs in countries. This similarity coincides with many authors' opinion that a country is a type of region. That is, in cases of CouLPs and RLPs we consider an RLP a type of LP similar to how a country is a type of region.

By creating matrices of categories and conducting a cross-case examination in search for patterns, it was found that geographical position is always emphasized in relation to CouLPs and RLPs. Despite an initially perceived similarity, ComLPs and SCLPs differ. In the case of the ComLPs and SCLPs, geographical position refers to a spe- 
cific location within a broader area (i.e., a specific street address), while with RLPs and CouLPs, geographical position refers to a wider area of the region/country. In the case of ComLPs, infrastructure is privately held, whereas, in the case of RLPs and CouLPs, infrastructure is publicly owned or in a public-private partnership. Logistics experts are also mentioned in relation to all three areas. Another difference is that CouLPs and RLPs plan and maintain training systems for logistics experts, while companies employ logistics experts, enhancing/renewing their human resources within ComLPs.

\section{Is RLP formation a result of established regional strat- egy?}

In all examined cases, the emergence and operation of LPs, regardless of type, proved to be a result of realizing certain strategies, namely:

- Company level: To develop effective logistics to increase a company's competitiveness;

- SC level: To effectively communicate with most partners through a single interface and to achieve and maintain the SC's competitiveness;

- Country and regional level: To create a favourable business environment for attracting and operating logistics and manufacturing companies and to increase the economic welfare of the country/region.

LPs do not develop by accident. Their beginnings may be spontaneous until a critical mass of interested stakeholders emerges with a clear vision and start-up energy for a breakthrough. All LPs are centrally managed and based on logistics and process knowledge.

RLPs and CouLPs have similar, if not identical, strategies. Their only difference lies in the characteristics of the geographical area in which they operate. In the case of CouLPs, areas are clearly outlined by a country's borders.

\section{What are the effects of RLP implementation?}

Considering the data, we observed many benefits of LPs' existence and operation. The most important one is making the region more logistically friendly. We synthesized the rest by the following area types:

- Company level: companies equalize LP within a distribution centre, construction of which can result in increased flexibility, responsiveness, and sustainability of distribution activities, the effective adaptation of the company's logistics activities to changes in marketing and sales strategy, feasible and timely business expansion into new markets and lower costs of logistics for companies.

- SC level: The standardization of logistics processes, lower logistics' costs on the SC level, faster material flows, less operational work/more analysis, the rapid integration of new partners, fewer negative impacts of cultural differences (major obstacle according to
Tušar et al. (2016)).

- Country and regional level: The dissemination of knowledge in the field of logistics, balanced/innovative/sustainable development of the logistics sector in the country/region, an attractive business environment for the placement and operation of (logistics) companies, clear guidelines for the development of a logistics sector in the region, joint participation of the country/regional logistics sector in the market.

Again, we noted almost no major differences between the reported benefits of regional and country LPs.

During the case study, we observed a European logistics platform that occurred in 2013 (European logistics platform 2015). Its existence could not be predicted from the review of scientific articles. We understand this new formation as an attempt of the European Union's logistics specialists to eliminate the disadvantage of other types of researched LPs that are of "distinctly local interest“ in a narrow geographic/business area. This is probably one of the drivers for the emerging hierarchical LPs (e.g., the European logistics platform).

\subsection{Survey Results}

Of the 160 participants in Slovenia and Poland who returned questionnaires, $67.5 \%$ were already familiar with the LP concept. According to the binomial test's results, it may be assumed that fewer than $70 \%$ of logistics managers employed in logistics companies $(\mathrm{p}=0.045)$ and fewer than $75 \%$ of logistics managers employed in non-logistics companies $(\mathrm{p}=0.027)$ had encountered the LP concept.

The data collected from the study's survey were analysed in three phases, as described below. During each phase of the analysis, the presence of statistically significant conflicting opinions among Slovenian and Polish respondents was also verified.

\section{The relationship between each constituent and the con-} cept of LP

The 52 Slovenian and 56 Polish individuals familiar with LP were asked which constituents the term LP included, irrespective of where the term had been observed. The vast majority of respondents confirmed that using LP more or less strongly encompasses all proposed constituents. Few respondents selected „Did not include.” These were: 12 for business environment, 11 for geographical position, 11 for joint interactive portal, 10 for traffic infrastructure, nine for organized group of stakeholders, eight for logistics specialists, seven for regulations for logistics companies ${ }^{6}$ needs, five for ICT logistics support, two for logistics technological equipment, one for logistics technology, and one for logistics companies.

Results of the Kruskal-Wallis H test (Field, 2005) and Mann-Whitney test indicate that different types of or- 
ganizations (LC, PnLC, PBp) within and across different countries do not have significantly different perceptions in terms of the affiliation between each of the proposed constituents and the LP concept.

The relationship between each geographic / business area and the concept of LP

The participants were also asked to identify areas (company, SC, country, region) in which LPs were implemented and to what extent. The respondents almost confirmed that LPs were implemented in all proposed areas. Only a few respondents selected „I completely disagree. These were: 35 for implementation of LP in a single organization, 17 for implementation of LP on SC scope, nine for implementation of LP on a country scope, and four for implementation of LP on a regional scope. The results of the Kruskal-Wallis H test and Mann-Whitney test indicate that different types of organizations within and across different countries do not have significantly different perceptions of the types of geographic/business areas in which LPs are implemented and the extent to which they are implemented.

\section{The relationship between each constituent and each ge- ographic/business area}

Nearly all respondents confirmed that all of the constituents and areas proposed were included in the written and oral sources that the respondents used to become familiar with the concept. Since none of the respondents entered an additional constituent or area, we assume that all constituents and areas were included in the model and questionnaire.

Based on the case study's results, we expected that respondents would confirm our observed links between the proposed LP constituents and the geographic/business areas in which LPs are implemented. To verify, we used bivariate correlation (more specifically, the Spearman correlation coefficient). The results are presented in Figure 2.

Respondents observed a weak link between company area and the following constituents: logistics technological equipment $(\mathrm{rs}=0.375, \mathrm{p}<0.01)$; logistics technology $(\mathrm{rs}=0.322, \mathrm{p}<0.05), \mathrm{ICT}(\mathrm{rs}=0.300, \mathrm{p}<0.05)$; and logistics specialists $(\mathrm{rs}=0.283, \mathrm{p}<0.05)$. Furthermore, respondents perceived a weak link between the SC area and the following constituents: business environment $(\mathrm{rs}=0.304, \mathrm{p}<0.05)$; logistics infrastructure ( $\mathrm{rs}=0.276, \mathrm{p}<0.05)$; logistics technology ( $\mathrm{rs}=0.287, \mathrm{p}<0.01)$; ICT $(\mathrm{rs}=0.346, \mathrm{p}<0.05)$; and logistics companies ( $\mathrm{rs}=0.322, \mathrm{p}<0.05)$. Respondents moderately associated the area of SC with logistics technological equipment $(\mathrm{rs}=0.551, \mathrm{p}<0.01)$ and logistics specialists $(\mathrm{rs}=0.484, \mathrm{p}<0.01)$ and observed a weak positive correlation with company area and business environment $(\mathrm{rs}=0.355, \mathrm{p}<0.05)$ and transport infrastructure $(\mathrm{rs}=0.335$, $\mathrm{p}<0.05$ ), and a moderate correlation with geographic loca-

\begin{tabular}{|c|c|c|c|c|c|c|c|c|}
\hline \multirow{2}{*}{ Constituents } & \multicolumn{3}{|c|}{ Case study } & \multicolumn{4}{c|}{ Survey } \\
\hline & Geographical/Business Area & \multicolumn{3}{c|}{ Geographical/Business Area } \\
\hline & Com & SC & Cou & R & Com & SC & Cou & R \\
\hline Geographical position & & & & & & & $.464^{* *}$ & $.476^{* *}$ \\
\hline Business environment & & & & & & $.304^{*}$ & $.355^{*}$ & $.416^{* *}$ \\
\hline Traffic infrastructure & & & & & & & $.335^{*}$ & $.495^{* *}$ \\
\hline Logistics infrastructure & & & & & & $.276^{*}$ & & \\
\hline Logistics technological equipment & & & & & $.375^{* *}$ & $.551^{* *}$ & & \\
\hline Logistics technology & & & & & $.322^{*}$ & $.387^{* *}$ & & \\
\hline ICT logistics support & & & & & $.300^{*}$ & $.346^{*}$ & & \\
\hline Logistics specialists & & & & & $.283^{*}$ & $.484^{* *}$ & & \\
\hline Logistics companies & & & & & & $.322^{*}$ & & $.361^{* *}$ \\
\hline Regulations for logistics companies \\
needs & & & & & & & & $.268^{* *}$ \\
\hline Joint interactive portal & & & & & & & & \\
\hline Organized group of stakeholders & & & & & & & & $.392^{* *}$ \\
\hline
\end{tabular}

Figure 2. Correlations between constituents and geographic/business areas, based on case study and survey data

*. Correlation is significant at the 0.05 level (2-tailed)

**. Correlation is significant at the 0.01(2-tailed) 
tion ( $\mathrm{rs}=0.464, \mathrm{p}<0.01$ ). According to the respondents, the regional area is weakly associated with logistics companies ( $\mathrm{rs}=0.476, \mathrm{p}<0.01)$ and organized group of companies $(\mathrm{rs}=0.392, \mathrm{p}<0.01)$ and is moderately associated with geographic location $(\mathrm{rs}=0.474, \mathrm{p}<0.01)$, business environment $(\mathrm{rs}=0.416, \mathrm{p}<0.01)$, and transport infrastructure ( $\mathrm{rs}=0.495$, $\mathrm{p}<0.01)$.

\section{Discussion}

The LP concept is contemporary and evolving mostly in the EU and South America. The outcomes of the Singapore survey suggest that although participants from Singapore were unaware of the "logistics platform" by name, the country developed one named Singapore logistic hub, an obvious theoretical example of RLP as LP's sub-type. Logistic hub is a platform for inter-organizational links that would enact "something more within a specific local environment" in order to gain more in the field of logistics (Gajšek \& Rosi, 2015). LP is a hypernym, developing itself into a hierarchical, multi-level structure. Later is concluded on results of above described research, in which, in the first step, the characteristics of professional terms within hypernym were defined. In the second step, four sub-types of LP were defined according to observed repetition patterns. Four geographic/business areas of implementation were defined, namely company, SC, country, and region. Scientific articles, mentioned in the literature review, suggest that the term LP is used globally, but, as noticed, with different frequencies in different parts of the world. Company's and SC's LPs are evidently globally present. Multi-level structure, in the sense that the ComLPs are parts of the SCLP, the SCLPs are parts of the CouLP and one or mere CouLPs are parts of the RLP, is logical and demonstrable because of the nature of direction of material flow, which is present between companies within supply chains, which operate within countries and regions. It is necessary to emphasize that academics primarily characterize the LP concept as being conventional and single-layered. Research shows that such conceptualization is outdated. In following sentences, the hierarchy is explained from the bottom up (i.e., from the individual company to the group of companies). A single company manages its own ComLP, consisting only of the company's logistics resources. A central company of the SC (usually the manufacturer/an assembly company/wholesaler) in collaboration with suppliers working alongside the SC develops, manages, and operates an SCLP. The central company may have its own LP sources used for logistics activities, or ownership may be divided among SC members. Each company may also have its own ComLP.

We compared the findings of this study's qualitative and quantitative components, and the overlapping areas are presented in Figure 2. The results of the case studies and the survey confirmed the existence of different fre- quently mentioned constituents in relation to different areas of LP implementation (Figure 2). Consequently, we can confirm that LPs, applied to different geographic/business areas, significantly differ according to the most frequently mentioned constituents. As such, these findings are consistent with TCE, RBV and SSP theories. Researchers only recently started to explore governance models for ComLP and SCLP. Unlike that, governance models for RLP and CouLP still represent a great opportunity for exploration. We currently know only their most frequently mentioned constituents, namely organized group of stakeholders, the joint interaction portal, and regulations to manage RLPs and CouLPs. Future research needs to include studying logistics and transportation governance models in countries, and regions inside them. Perhaps multinational companies will not become stakeholders in development of regional logistics and transportation formations, but countries and their regions should be to have a control and influence on their incomes, employment of citizens, and environmental impacts.

In this study, from here on, we particularly focus on RLPs. Although regions and countries often place transport infrastructure's development solely at the forefront of their development plans; that is not the case in countries with a higher LPI (Germany, Denmark, France, and Spain). Logistics services can develop at a faster pace than before based on improved intermodal transport and logistics infrastructure supported by a joint interactive portal supporting promotion and marketing sites, a catalogue of logistic companies and services, electronic auctions, news on traffic jams, accidents, planned works, information on excess capacities, and similar factors. A portal should be developed to facilitate a clear depiction of logistics and transportation developments in the given region. Case studies show that balanced parallel development of the aforementioned factors is of major importance in addition to logistic professionals' proactive education. The described approach distinguishes leaders from followers. This approach suggests that RLPs require coordinated development of transport infrastructure, logistics infrastructure, and ICT support to regional logistics management and operations, which appear because of regions' own codified management and coordination mechanisms for the development and operation of their unique logistics systems. Unlike RLPs, ComLPs try to balance characteristics of companies' private logistics infrastructure, logistics equipment and technology, logistics software and logistics specialists within their walls. In contrast to RLPs and ComLPs, SCLPs try to standardize exchange processes with free logistics software offered to partners, thus indirectly influencing the choice of unified software support, logistics technology, and logistics equipment for partners within the SC.

Case studies have shown numerous advantages of all types of LPs. However, there is no trace of a mass deploy- 
ment in practice, especially in the context of countries and regions, even if we research phenomena called by other professional terms within hypernym "logistics platform". An inhibiting factor we have seen is the absence of codified management and coordination mechanisms for the development and operation of a defined logistics system. Scientific literature most commonly emphasizes the LP concept as a set of systematically pooled constituents. Additionally, practice shows that a set of systematically pooled constituents is a result of the aforementioned mechanism's healthy functioning. Thus, the research suggests that different types of LPs, including RLP, evolve because of the emergence of mechanisms for managing and coordinating a defined logistics system's development and operations, which is not well researched.

Based on our research results, we propose the following general definition of LP, which also applies to RLP as sub-type. An LP represents the management and coordination of a particular logistics system's development and operation and a set of constituents that are systematically pooled because of this system's operation (Figure 3).

The LP is always part of the logistics system, which may be divided among a variety of active members, which vary according to LP type. For example, regional logistics system includes following members:

- companies in the role of logistics and transportation service providers;

- users of logistics services;

- regional network connections within the logistics and transport sectors;

- operators of transport infrastructure;

- operators of logistics infrastructure;

- providers of ICT net and related services;

- operators of the innovative supportive environment;

- stakeholders, including local communities;

- public authorities.

Regional logistics service providers that include the formation of an RLP may participate in the following ways:

- as one of RLP's constituents within a pooled set of constituents;

- as co-creator of the RLP through membership in a regional logistics association;

- as both.

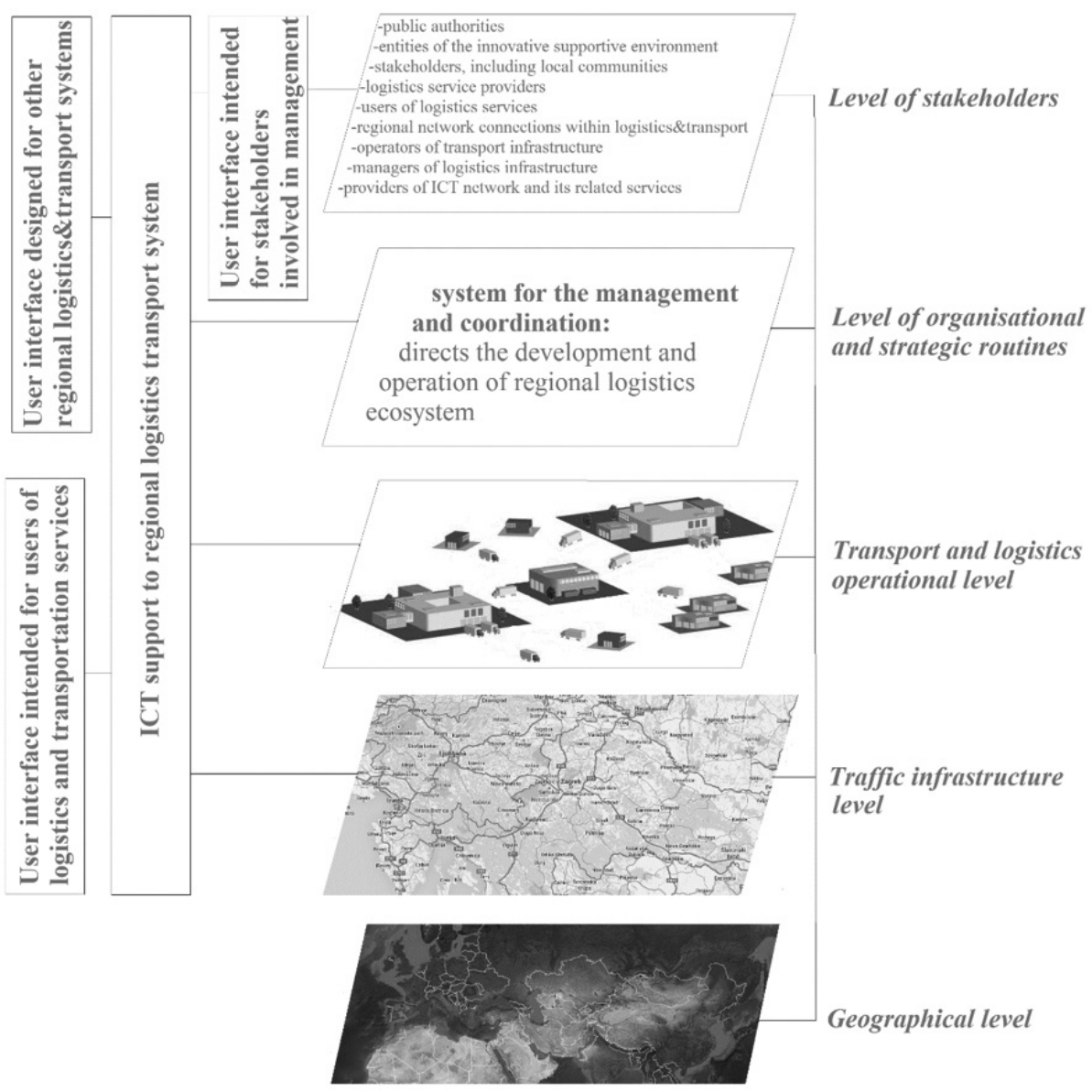

Figure 3: RLP general model 
Viewed from a specific region's perspective, logistics service providers operating in surrounding regions may rent their missing constituents and exploit them within their own business LPs on the principle of "hire and distribute," or they may purchase RLP's services, indicating the hierarchical relationship between them.

The main purpose of creating RLPs is to support the efficient and effective implementation of national or regional logistics development strategies, targeting optimal economic and environmental welfare of the region/country. Additional purposes include the following:

- promote the region as a place to carry out effective, innovative and sustainable logistics and transport processes;

- connect all stakeholders interested in logistics and transport;

- continuously detect opportunities and challenges in the fields of logistics and transport;

- promote cooperation in terms of special opportunities and needs;

- comprehensively and professionally support the positioning of transport and logistics infrastructure within the regional geographic area;

- encourage innovation and raise the level of competence in the fields of logistics and transport in the region;

- enable stakeholders to meet to exchange knowledge and experience;

- enable stakeholders to conduct business activities in a modern, innovative and efficient manner.

The main objectives of creating an RLP are economic growth and improved economic competitiveness within the region. Other objectives are the following:

- regional strength and steady economic growth in the logistics and transport sectors;

- increased number of staff employed in the logistics and transport sectors;

- the establishment of IC support for logistics and transport activities in the region;

- reduced $\mathrm{CO}_{2}$ emissions and increased energy efficiency;

- increased use of renewable energy sources;

- improved business environment indicators;

- increased level of co-modality;

- the joint promotion of logistics and transport within the region.

Members of regional logistics systems invest their time and ideas in all cooperating entities' shared future, in which they anticipate profiting together. All stakeholders can expect to benefit greatly. Some of these anticipated benefits are described below.

Companies acting as logistics service providers can reduce operating costs by using the logistics infrastructure in a public-private partnership, undertaking joint promotion and marketing activities, using common ICT support, or improving access to infrastructure. By jointly appearing on the market, these companies have a greater possibility of acquiring new customers. Also, companies become more attractive for a wider range of potential customers. They have the opportunity to influence developments in logistics and transportation.

An RLP can help users of logistics services by providing a faster search for more cost-efficient and customizable service providers. They can lower the risk of accidents that could result in damaged cargo, and they can receive services that are more innovative and of higher quality.

Operators of an innovative supportive environment receive primarily indirect financial benefits. They can design more comprehensive regional development programs including not only transport but also logistics content. In the eyes of consumers and the entrepreneurial sector, these operators have a greater impact on promoting competitiveness as well as improving human resource development, quality of life, and sustainable development. RLPs provide an ideal environment for exploiting their full potential, in turn requiring less infrastructure to benefit more businesses.

RLPs are important for local communities that otherwise hardly have a voice while preparing spatial arrangement plans. Logistics and transport sectors are not limited to industrial zones. Trade flows can also significantly affect quality of life. Local communities can participate in policy-making processes, exchange views with experts, and indirectly improve their quality of life.

The crucial and the most important RLP actor is a type of association within the logistics and transport sectors. If logistics service providers are unable to organize themselves at the regional level, the importance and potential of logistics are likely to be overlooked, and logistics issues are excluded from regional development programs. An association under an RLP provides the following: effective knowledge transfers among logistics service providers, greater bargaining power, possibilities for access to different types of public fund subsidizing, most logistics service providers' greater belonging to the logistics sector, realization of synergies, increased motivation for introducing new technologies and innovation, and participation in policy making.

As enablers of industrial initiatives, public authorities are convinced of RLPs' relevance and benefits. In practice, business subjects or operators are not necessarily willing to follow this initiative, even if it is subsidized. However, if willingness exists (usually in the form of a logistics association), then public authorities can achieve strategic regional strategy objectives through an RLP.

RLPs' listed benefits are mainly of a macroeconomic nature, such as a more acceptable carbon footprint, increased competitiveness of enterprises in the region, a faster return on investment in transport infrastructure, a more attractive business environment, and established conditions for creating new jobs with higher added value. Therefore, owners and operators of ComLPs and SCLPs 
can expect to receive direct financial benefits at the micro level.

Companies and SCs provide their services in logistically friendly regions and countries around the globe. Logistical friendliness can be linked to RLP's and recently with the European Union's logistics platform. The latter is an attempt of the European Union's logistics specialists to eliminate the disadvantage of hierarchically lower types of LPs, that is, ,distinctly local interest“" in a particular narrow geographic/business area (i.e., company, SC, country, region) and to become a means for the European Union's economic growth.

\section{Conclusions}

This paper's primary goal has been to design an RLP conceptual framework that on a theoretical level links different views of LPs. As such, it assists not only researchers in creating new organizational models but also regional authorities in achieving regional economic growth. We compared characteristics of LPs' theoretical concepts with examples taken from practice to gain an understanding of how the LP term has been employed by mostly European stakeholders. Specifically, we focused on the types of constituents and geographic/business areas that LPs cover.

First, we studied academic definitions surrounding logistics and non-logistics platforms, anticipating that the concept of an LP would be realized as one of the following:

- one or more principles/resources/constituents or their combination;

- prerequisite for the continuation of activities (e.g., contract, financial input, letter of intent, project documentation, order);

- surface area (i.e., traffic route, parking lot);

- system (warehouse as a black box with all movable and immovable assets, personnel, IT support, etc.);

- any combination of the previous options that are needed for designing/planning/implementing/controlling logistics processes or logistics activities.

In addition to an LP's specific description, a detailed description of its constituents and area must be considered. We considered 12 such constituents: logistics infrastructure, logistics technological equipment, logistics technology, logistics experts, transport infrastructure, ICT, joint interactive portal, regulations, business environment, geographical location, organized group of companies, and logistics companies. We also considered four geographic/business areas: company, supply chain, country, and region. According to this result, four subtypes of LP had been proposed, namely ComLP, SCLP, CouLP and RLP.

We noted two views of the LP concept that results in differing definitions. One group of authors views LPs as necessary parts of a larger whole (i.e., one logistics cen- tre for all distribution activities). Another group of authors understands LP as a base for various constituents that may not all be engaged in all activities (i.e., customized services); however, they are all compatible.

We cannot determine, which of the 12 proposed constituents are not parts of an LP within a specific geographic/business area. However, we can predict which constituents are of greater importance for an LP within a specific geographic/business area. More frequent discussion means greater perceived importance of such activities like planning and colluding.

We proposed a general definition of an LP, its subtypes, a general model of an RLP, and RLPs' goals and benefits for stakeholders. As a result of our research, it is possible to classify existing LPs and to create new LPs according to a given strategy, strategic objectives, desired benefits and covered geographic/business areas.

The secret of a successfully developing a logistics region lies in its ability to develop a mechanism for the managing and coordinating a particular logistics system's development and operation, an area that should be further researched. Due to the system's operations, a set of pooled constituents occurs spontaneously. Before this mechanism's occurrence, logistics service providers may need years to organize themselves within a kind of association that can participate in policy development processes. They must not only outgrow the phase in which they view each other as mere competitors, but also find a common interest and expand the scope of their synergic operations. The LP concept is a proven, multi-level phenomenon that should be further explored as a mechanism for co-opetition and collaborative consumption.

We propose more frequent operationalization of new institutional economics and social network theories as the basis to examine the integration of regional logistics and transportation stakeholders based on the proven links between constituents and LP types. In closing, RLPs as a type of LP are essential for maximizing regional earnings via performing logistics and transport activities, preservation of the environment and activation of regional resources.

\section{References}

Abrahamsson, M., Aldin, N. \& Stahre, F. (2003). Logistics Platforms for Improved Strategic Flexibility. International Journal of Logistics: Research and Applications, 6(3), 85-106, http://dx.doi.org/10.1080/1367556 031000123061

Almotairi, B. (2012). Integrated Logistics Platform - The context of the port relational exchanges and systematic integration. Göteborg: Department of Technology Management and Economics and Chalmers University of Technology.

Antún, J.P. \& Alarcón, R. (2014). Bases for feasibility analysis of Logistics Platforms at borders. Procedia - 
Social and Behavioral Sciences, 162, 6-14, http://dx. doi.org/10.1016/j.sbspro.2014.12.180

Arvis, J.F., Saslavsky, D., Ojala, L., Shepherd, B., Busch, C. \& Raj. A. (2014). Connecting to Compete $2014-$ Trade Logistics in the Global Economy - The Logistics Performance Index and Its Indicators. Washington: The World Bank.

Barney, J. (1991). Firm resources and sustained competitive advantage. Journal of Management, 17(1), 99120.

Berqvist, R. \& Monios, J. (2014). The role of contracts in achieving effective governance of intermodal terminals. World Review of Intermodal Transportation Research, 5(1), 18-38, http://dx.doi.org/10.1504/WRITR.2014.065040

Blatter, J. (2003). Beyond Hierarchies and Networks: Institutional Logics and Change in Transboundary Spaces. Governance, 16, 503-526, http://dx.doi. org/10.1111/1468-0491.00226

Bolumole, Y.A., Closs, D.J. \& Rodammer, F.A. (2015). The Economic Development Role of Regional Logistics Hubs: A Cross-Country Study of Interorganizational Governance Models. Journal of Business Logistics, 36, 182-198, http://dx.doi.org/10.1111/jbl.12088

Bonev, M., Wörösch, M. \& Hvam, L. (2015). Utilizing platforms in industrialized construction. Construction Innovation, 15(1), 84-106, http://dx.doi.org/10.1108/ CI-04-2014-0023

Cambra-Fierro, J. \& Ruiz-Benitez, R. (2009). Advantages of intermodal logistics platforms: insights from a Spanish platform. Supply Chain Management: An International Journal, 14(6), 418-421, http://dx.doi. org/10.1108/13598540910995183

Chen, H., Daugherty, P.J. \& Landry, T.D. (2009). Supply Chain Integration: A Theoretical Framework. Journal of Business Logistics, 30(2), 27-46, http://dx.doi. org/10.1002/j.2158-1592.2009.tb00110.x

Chikan, A. (2001). Integration of production and logistics - in principle, in practice and in education. International Journal of Production Economics, 69(2), 129140, http://dx.doi.org/10.1016/S0925-5273(99)001024

Christopher, M. \& Towill, D.R. (2002). Developing market specific supply chain strategies. The International Journal of Logistics Management, 13(1), 1-14, http:// dx.doi.org/10.1108/09574090210806324

Clifford Defee, C. \& Stank, T.P. (2005). Applying the strategy-structure-performance paradigm to the supply chain environment. The International Journal of Logistics Management, 16(1), 28-50, https://doi. org/10.1108/09574090510617349

Closs, D.J., Bolumole, Y.A. \& Rodammer, F. (2014). Supply Chain Management Opportunities for Regional Economic Development. Transportation Journal, 53(4), 453-98, http://dx.doi.org/10.1353/ tnp. 2014.0025
Coase, R.H. (1937). The nature of the firm. Economica, 4(16), 386-405.

De Carvalho, C.C., De Carvalho, M.F.H. \& Lima, O.F.Jr. (2010). Efficient Logistic Platform Design: The Case of Campinas Platform. Paper presented at the XVI International Conference on Industrial Engineering and Operations Management, São Carlos, SP, Brasil, October 12-15.

De Souza, F.M., Da Silva Costa, W.A. \& Gobbo Junior, J.A. (2007). Logistic platforms: Proposal of an implementation methodology. Paper presented at the POMS $18^{\text {th }}$ Annual Conference, Dallas, Texas, U.S.A., May 4-7.

Del'olmo, P. \& Lulli, G. (2004). Planning Activities in a Network of Logistics Platforms with Shared Resources. Annals of Operations Research, 129(1-4), 155-169, http://dx.doi.org/10.1023/ B:ANOR.0000030686.79587.60

Du, J. \& Bergqvist, R. (2010). Developing a conceptual framework of international logistics centres. Paper presented at the 12th WCTR, Lisbon, Portugal, July $11-15$.

Dubke, A.F., Ferreira, F.R.N. \& Pizzolato, N.D. (2006). Plataformas Logísticas: Características e tendências para o Brasil. Paper presented at the XXIV ENEGEP, Florianópolis, SC, Brasil, November 3-5.

Dyer, J.H. \& Singh, H. (1998). The relational view: Cooperative strategy and sources of interorganizational competitive advantage. Academy of Management Review, 23(4), 660-679, https://doi.org/10.5465/ AMR.1998.1255632

Ellram, L.M. (1996). The use of the case study method in logistics research. Journal of Business Logistics, 17(2), 93-138.

European Commission (2015). Fact-finding Studies in Support of the Development of an EU Strategy for Freight Transport Logistics. Lot 1: Analysis of the EU Logistics Sector - Final Report. http://ec.europa. eu/transport/themes/strategies/studies/doc/2015-01freight-logis tics -lot1-logistics-sector.pdf

European logistics platform (2015). Our Mission. http:// www.european-logistics-platform.eu/

Field, A. (2005). Discovering statistics using SPSS, 2nd ed. London: SAGE Publications.

Francetech (2001). France - The country of choice for logistics. http://archives.entreprises.gouv.fr/2012/www. industrie.gouv.fr/biblioth/docu/dossiers/sect/pdf/logistic broch gb.pdfGattuso, D. \& Cassone, G.C. (2012). Micro-simulation model supporting the management of an interregional logistics platform. Procedia - Social and Behavioral Sciences, 54, 557-566, http://dx. doi.org/10.1016/j.sbspro.2012.09.773

Gajšek B. \& Grzybowska K. (2013). A cross-county contextual comparison of the understanding of the term ,logistics platform' in practice. Research in Logistics \& Production, 3(2), 85-108. 
Gajšek, B. \& Rosi, B. (2015). Stakeholder differences in the understanding of inter-organizational concept content as a risk factor: The case for a logistics platform. International Journal of Logistics Management, 26(1), 107-127. https://doi.org/10.1108/IJLM-06-2012-0040

Golicic, S.L., Davis, D.F. \& McCarthy, T.M. (2005). Research methodologies in supply chain management. In: Kotzab, H., Seuring, R., Müller, M., Reiner, G., (Eds.). Research methodologies in supply chain management. Germany: Physica-Verlag.

Grzybowska K. \& Gajšek B. (2016). Supply Chain Logistics Platform as a Supply Chain Coordination Support. In: Bajo, J., Escalona, M.J., Giroux, S., Hoffa-Dąbrowska, P., Julián, V., Novais, P., Sánchez-Pi, N., Unland, R., Azambuja Silveira, R. (Eds.). Highlights of Practical Applications of Scalable Multi-Agent Systems. The PAAMS Collection. Germany: Springer, https:// doi.org/10.1007/978-3-319-39387-2_6

Guyon, O., Absi, N., Feillet, D. \& Garaix, T. (2012). A modeling approach for locating logistics platforms for fast parcels delivery in urban areas. Procedia - Social and Behavioral Sciences, 39, 360-368, http://dx.doi. org/10.1016/j.sbspro.2012.03.114

Jennings, B. \& Holcomb, M. (1996). Beyond Containerization: The Broader Concept of Intermodalism. Transportation Journal, 35(3), 5-13, http://www.jstor. org/stable/20713275

Johannsen, H.H.W. \& Kristiansen, J. (2007). Analysis of institutional and organisational solutions in the development of transport and logistics centres - based on illustrative examples. Denmark: Aalborg University.

Kille, C., Schwemmer, M. \& Reichenauer, C. (2015). TOP 100 in European Transport and Logistics Services 2015/2016. Hamburg: DVV Media Group.

Kinnear, E. (1997). Is there any magic in cross-docking? Supply Chain Management: An International Journal, 2(2), 49-52, http://dx.doi. org/10.1108/13598549710166096

Lăpăduşi, M.L. \& Căruntu, C. (2011). The role and the importance of the logistics platforms in internal and international transport. Annals of the Constantin Brâncuşi University of Târgu Jiu, Economy Series, 3, 205-209.

Lavie, D. (2006). The competitive advantage of interconnected firms: an extension of the resource based view. Academy of Management Review, 31(3), 638-58, http://www.jstor.org/stable/20159233

Leal, E. \& Pérez Salas, G. (2009). Logistic platforms: conceptual elements and the role of the public sector. Bulletin FAL, 274(6), 1-9. http://repositorio.cepal.org/ bitstream/handle/11362/36237/FAL_274_Logistic_ Plataforms.pdf?sequence $=1$

Lieb, R. \& Bentz, B.A. (2005). The North American third party logistics industry in 2004: the provider CEO perspective. International Journal of Physical Distribution \& Logistics Management, 35(8), 595-611, http:// dx.doi.org/10.1108/09600030510623357
Li-Ekenstedt, L. (2004). Decision Processes and Determinants of Logistics Facility Locations - Multinational Corporations' Perspectives. Göteborg: School of Business, Economics and Law, Göteborg University.

Lima, O.F., Rutkowski, E.W., De Carvalho, C.C. \& Lima, J.C.F. (2010). Sustainable Logistics Platform in a Regional Brazilian Airport. The International Journal of Sustainable Development and Planning, 2(5), 163174, http://dx.doi.org/10.2495/SDP-V5-N2-163-174

Lin, C.Y. \& Ho., Y.H. (2009). RFID technology adoption and supply chain performance: an empirical study in China's logistics industry. Supply Chain Management: An International Journal, 14(5), 369-378, http://dx. doi.org/10.1108/13598540910980288

Lin, Y., Luo, J. \& Zhou., L. (2010). Modular logistics service platform. Paper presented at the IEEE International Conference on Service Operations, Logistics, and Informatics (SOLI), Qingdao, Shandong, July 15-17, http://dx.doi.org/10.1109/SOLI.2010.5551582

Liedtke, G. \& Murillo, D.G.C (2012). Assessment of policy strategies to develop intermodal services: The case of inland terminals in Germany. Transport Policy, 24, 168-178, https://doi.org/10.1016/j.tranpol.2012.06.002

Mangan, J. \& Lalwani, C. (2008). Port-centric logistics. The International Journal of Logistics Management, 19(1), 29-41, http://dx.doi.org/10.1108/09574090810872587

Marasco, A. (2007). Third-party logistics: A literature review. International Journal of Production Economics, 113(1), 127-147, http://dx.doi.org/10.1016/j. ijpe.2007.05.017

Marolt, M., Lenart, G., Maletič, D., Kljajić Borštnar, M. \& Pucihar, A. (2016). Business Model Innovation: Insights from a Multiple Case Study of Slovenian SMEs. Organizacija, 49(3), 161-171, http://dx.doi. org/10.1515/orga-2016-0015.

Meidute, I. (2005). Comparative Analysis of the Definitions of Logistics Centres. Transport, 20(3), 106-110, http://dx.doi.org/10.1080/16484142.2005.9638005

Miles, R. E., Snow, C. C., Meyer, A. D. \& Coleman, H. J. (1978). Organizational strategy, structure, and process. Academy of Management Review, 3(3), 546-562, http://www.jstor.org/stable/257544

Monios, J. (2015). Integrating intermodal transport with logistics: a case study of the UK retail sector. Transportation Planning and Technology, 38(3), 347-374, http://dx.doi.org/10.1080/03081060.2015.1008798

Monios, J. \& Wilmsmeier, G. (2013). The role of intermodal transport in port regionalisation. Transport Policy, 30, 161-172, http://dx.doi.org/10.1016/j.tranpol.2013.09.010

Mozart da Silva, R., Senna, E.T.P. \& Senna, L.A.S. (2014). Governance of logistics platforms: The use of a survey for building a framework of performance indicators. African Journal of Business Management, 8(10), 350365, http://dx.doi.org/10.5897/AJBM2014.7360

Nguyen, H. O. \& Tongzon, J. (2010). Causal nexus be- 
tween the transport and logistics sector and trade: The case of Australia. Transport policy, 17(3), 135-146, https://doi.org/10.1016/j.tranpol.2009.12.005

Nunez-Carballosa, A. \& Guitart-Tarres, L. (2011). Third-party logistics providers in Spain. Industrial Management \& Data Systems, 111(8), 1156-1172, http://dx.doi.org/10.1108/02635571111170749

Pekkarinen, S. \& Ulkuniemi, P. (2008). Modularity in developing business services by platform approach. The International Journal of Logistics Management, 19(1), 84-103, http://dx.doi. org/10.1108/09574090810872613

Perez-Franco, R., Phadnis, S., Caplice, C. \& Sheffi, Y. (2016). Rethinking supply chain strategy as a conceptual system. International Journal of Production Economics, 182, 384-396, http://dx.doi.org/10.1016/j. ijpe.2016.09.012

Peters, N.J., Hofstetter, J.S. \& Hoffmann, V.H. (2011). Institutional entrepreneurship capabilities for interorganizational sustainable supply chain strategies. International Journal of Logistics Management, 22(1), 52-86, https://doi.org/10.1108/09574091111127552

Pfohl, H.C. \& Gareis, K. (2005). Supplier parks in the German automotive industry. International Journal of Physical Distribution \& Logistics Management, 35(5), 302317, http://dx.doi.org/10.1108/09600030510607319

Rutner, S.M., Aviles, M. \& Cox, S. (2012). Logistics Evolution: a Comparison of Military and Commercial Logistics Thought. The International Journal of Logistics Management, 23(1), 96-118, http://dx.doi. org/10.1108/09574091211226948

Sainza, R., Bañosb, J., Valc, S. \& Samir, J. (2013). The economic impact of logistics infrastructure: the case of PLAZA - the Zaragoza Logistics Platform. Transportation Planning and Technology, 36(4), 299-318, http://dx.doi.org/10.1080/03081060.2013.798480

Sanchez, O. \& Villalobos, J.R. (2007). Design of a Logistics Platform for the Distribution of Fresh Produce. Paper presented at the Informs Annual Meeting, Seattle, WA, November 4-7.

Schmitz, H. \& Nadvi, K. (1999). Clustering and Industrialization: Introduction. World Development, 27, 1503-14.

Schmoltzi, C. \& Wallenburg, C.M. (2011). Horizontal cooperations between logistics service providers: motives, structure, performance. International Journal of Physical Distribution \& Logistics Management, 41(6), 552-576, https://doi.org/10.1108/09600031111147817

Schwemmer, M. (2016). Die TOP 100 der Logistik. Hamburg: DVV Media Group.

Sprague, C. \& Woolman, S. (2011). VidaGas: delivering better health to Northern Mozambique with LPG. Journal of Enterprising Communities: People and Places in the Global Economy, 5(1), 41-57, http://dx- .doi.org/10.1108/17506201111119590

Stevens, G.C. \& Johnson, M. (2016). Integrating the Supply Chain ... 25 years on. International Journal of Physical Distribution \& Logistics Management, 46(1), 1942, http://dx.doi.org/10.1108/IJPDLM-07-2015-0175

Swiss Logistics Platform (2015). The Swiss Logistics Platform branch conspectus since 1999. http://www. logistikplattform.ch/wcms/logi.cfm/h,20/s, $0 / \mathrm{c}, 0 / \mathrm{sc}, \mathrm{en} /$ blue.htm

Tušar, M., Žnidaršič, A. \& Miglič, G. (2016). Differences Between National Cultures Matter - Case of Slovenian-Korean Working Environment. Organizacija, 49(3), 183-193, http://dx.doi.org/10.1515/orga-20160017

Váncza, J., Egri, P. \& Karnok, D. (2010). Planning in concert: A logistics platform for production networks. International Journal of Computer Integrated Manufacturing, 23(4), 297-307, http://dx.doi. org/10.1080/09511921003630092

Villa, A. (2001). Introducing some Supply Chain Management problems. International Journal of Production Economics, 73, 1-4, http://dx.doi.org/10.1016/S09255273(01)00090-1

Vogt, J.J. (2010). The Successful Cross-Duck Based Supply Chain. Journal of Business Logistics, 31(1), 99119, http://dx.doi.org/10.1002/(ISSN)2158-1592

Wernerfelt, B. (1984). A resource-based view of the firm. Strategic Management Journal, 5(2), 171-180, http:// dx.doi.org/10.1002/smj.4250050207

Williamson, O.E. (1975). Markets and Hierarchies: Analysis and Antitrust Implications. New York: The Free Press.

Brigita Gajšek is an Assistant Professor at Faculty of Logistics, University of Maribor. Her research interest includes processes, organization and technologies in intra-logistic.

Jure Kovač is a Professor of Organization and Management at Faculty of Organizational Sciences, University of Maribor. His research interests are organization theory, organization design and management development.

Major Benjamin T. Hazen, PhD is an Assistant Professor of Logistics and Supply Chain Management in the Department of Operational Sciences at the Air Force Institute of Technology. He is also a Faculty Affiliate of the Department of Marketing and Supply Chain Management at the University of Tennessee. He has published more than 50 peer-reviewed articles in leading journals. 